\title{
Disease Qualifier
}

National Cancer Institute

\section{Source}

National Cancer Institute. Disease Qualifier. NCI Thesaurus. Code C27992.

An adjectival term used to specify and describe a disease appearance or processes. 